\title{
Exploring Sensibility in Modern Indian English Drama
}

\author{
Vitthal V. Parab \\ Department of English, K.M. Agrawal College of Arts, Commerce \& Science, Mumbai, India
}

\begin{abstract}
The Indian English Drama has developed as an important and versatile body of English Literature and has caught attention of the global audiences. It has made a substantial progress by encapsulating various issues that India has been facing from time to time. It finds its impetus from Indian sensibility, philosophy, myths and religious beliefs and attracted attention of the people beyond boundaries. When one goes through the history of Indian English Drama, one comes to know that it has made a little progress than Indian English Fiction and Poetry. Though Indian English Drama came to the scene before these abovementioned genres but failed to keep pace with them because of some reasons. Unlike Fiction and Poetry, Drama cannot be restricted to reading only. It needs a theatre, an encouraging audience, effective dialogues, efficient actors and other stagecraft. Indian English Drama passes many phases and at last comes to a whole new range of playwrights who have left no stone unturned to give it its due place. The present paper studies Indian English Drama with all its flaws and highlights the contribution of Modern Indian English Playwrights.
\end{abstract}

Key words: Substantial progress; Onslaughts; Globalization; Indian sensibility modern age with modern Indian English playwrights.

\section{Introduction}

Be it Greek, Roman, English or Indian, Drama has always been a carrier of social and political changes. Premised on cultural and religious convictions, it has always tried to solve human mysteries through live presentation on a stage before an audience. Drama is an ancient Greek word meaning 'act' or 'deed'. The Ancient Greek philosopher Aristotle used this term in the Poetics. He used the term 'drama' to describe poetic compositions that were 'acted' in front of audiences in a theatron. But in India, there developed another very influential drama theory independently of western drama. It is Natyasastra by the Indian theorist Bharata. It is a classical text which classifies drama very effectively. Its system of classification has profoundly influenced the development of Indian dramatic forms and theories. History of Indian drama starts with the ancient Vedic age, moves on the classical theatre tradition, passing through regional dramas as Hindi, Marathi, Bangali down the line to the exploration of new vistas in The present paper aims to throw light on the problems before Indian English Drama and the contribution of Modern Indian English Playwrights to further dramatic literature and performances.

The journey of Indian drama starts with Sanskrit drama in India. Sanskrit drama was based on the Rasa theory of Muni Bharata. Dialogues were the mixture of verse and prose. Bhasa's thirteen Sanskrit plays are the earliest surviving complete plays. Shakuntala by Kalidasa is the finest of Sanskrit plays. It is one of the oldest plays based on the great epic Mahabharata which becomes the source of many other Indian English Dramas. Apart from Bhasa and Kalidasa, the contribution of Sudraka and Bhavbhuiti is also great. Mudrarakdhasa by Sudraka and Uttararamachari by Bhavbhuti were unmatchable plays. These playwrights and their plays show the rich dramatic tradition in Ancient India. Sanskrit drama is different from the Greek drama in the sense that it defies categorization into tragedy and comedy. The Greek plays were intended for masses while the Sanskrit drama was presented before the men of scholarship. The aim of the Sanskrit drama is the realization of Rasa as prescribed in Natyashastra. Indian English drama starts its journey with the publication of The Persecuted by Krishna Mohan Banerjee in 1831. Since this publication, many plays have been written in original English, many have been translated from regional languages and some have been staged also. But there is no denying the fact that Indian Drama in English is considered less fortunate in comparison with Indian English poetry and fiction. According to K R Srinivasa Iyengar: "Modern Indian dramatic writing in English is neither rich in quantity nor, on the whole, of high quality. Enterprising Indians have for nearly a century occasionally attempted drama in English-but seldom for actual stage production." (226) various factors are responsible for the unsatisfying growth of Indian English 


\section{Yinternational Research Journal}

p-ISSN 2202-2821 e-ISSN 1839-6518 (Australian ISSN Agency)

Drama. One of them, as suggested by Iyengar, is stage unworthiness of the plays.

The next requisite of drama is a living theatre. M.K.Naik in his article says, "Drama is a composite art in which the written words of the playwright attains complete artistic realization only when it becomes the spoken word of the actor on the stage and through that medium reacts on the mind of the audience. A play in order to communicate fully and become a living dramatic experience thus needs a Real theatre and a live audience." (180-181). Thus lack of a living theatre and enthusiastic audience have really hampered the natural growth of Indian English Drama. The major setback in the growth of Indian English Drama is language. English which is not the mother tongue of India poses many barriers before the actors and the audience. Being foreign language, it affects the most important factor of drama that is natural conversation. The Indian characters are not able to speak fluently. Supriya Shukla finds: "the inherent inadequacy of the English language to express temperaments, sensibilities, and realities which are essentially Indians." (9). Indian drama has flourished in regional languages and Indian English Drama is a translation of it to a great extent. So translation, as it

is obvious, is always an approximation which lacks natural expression.

Drama is meant to be staged. It should also provide some incentive to the playwright which depends on the professional stage and box office. But with the advent of talking films in 1930, drama faced downfall. Films provide more refined entertainment at the cheaper rates. The performances of Indian English Drama have also been affected by regional drama. After independence, National School of Drama was established but only a few plays were staged there in a year. Not only this, performances were rarely repeated. UNESCO affiliated theatres like Indian People's Theatre and Indian National Theatre were not entirely devoted to drama in English. They became the medium to stage regional drama.

Theatres were established in three major cities Calcutta, Madras and Bombay under British Rule. The people of these cities were highly influenced by British way of living and the "social values of this class were shaped by the English education it has received." (Karnad 4) This was the time when theatre companies from England used to visit India to entertain English people in India. It left an indelible impact on the Indians in these cities also. The Indian theatrical taste underwent a sea change. Before nineteenth century there was no fee for watching a play. Theatre depended on patronage of kings, ministers or temples. The improvisation of the actors with the given narrative material determined the success of the play. Like folk and traditional theatrical forms, actors did not
Vol. 06 No. 012016

82800601201602

learn their dialogues and rehearse for the same. But as soon as the box office started assessing the success of a play, drama became a matter of more conscious effort.

Parsi theatre has also its importance in the journey of drama. It promoted secularism and egalitarian at one hand, while on the other it remained loyal to traditional notions of caste and religion. In duration of nearly seventy-five years it did not produce drama of much worth. It had many features like music, mime and comic scenes of traditional arts. But it is equally true that it could not inspired Modern Indian English Drama much. In the absence of urban and Hindu tradition of history, the writers like Girish Karnad had to look upon the Parsi stagecraft. When Karnad thought of writing Tughlaq, he had to use the techniques of Parsi Theatre. Parsi theatre had a succession of shallow and deep scenes. These scenes confirmed hierarchy between high and low classes. Shallow scenes were meant to be held in the streets or outside while deep scenes required royal palace or parks at the backdrop. Shallow scenes were acted by the low class actors while deep scenes were acted by the actors of high class. But Karnad found it very difficult to maintain this separation. Karnad admits: "for the first time in its history I found the shallow scenes bulging with an energy hard to control." ( Dodiya 28) . During 1930 there came Realistic Drama which was highly inspired by George Bernard Shaw. It aimed to reform the society. But the living-room policy which was the hallmark of western realistic plays got failed in the traditionally framed Indian set-up.

The deep study of Indian English Drama makes it clear that the playwrights are also responsible for the poor state of Indian English Drama. They relied more on western models and techniques. The playwrights like Sri Aurobindo and Rabindranath Tagore, allowed themselves to be influenced by the Elizabethan drama and did not make use of the traditional Sanskrit theatre and folk-stage of our country. Tagore's plays are highly complex and psychological in nature. In Perseus, the Viziers and other plays, Sri Aurobindo strictly resorts to the Elizabethan model - particularly the five-plot structure, sub-plots and lengthy speeches in verse. Though Kailasam shows a better stage sense than Sri Aurobido, he too does not evince much technical innovation. He does not show the same liking towards the techniques of our classical drama. Though he does not fully follow Sri Aurobindo in adopting Elizabethan models and techniques, he is not completely free from their influence. In fact, he tries, though unsuccessfully, to cast the lives of his heroes like Karna into the Elizabethan mould of a tragic hero. His Keechaka suffers from excessive idealization because unlike Keechaka of Mahabharata, his Keechaka is a man of loyalty and honor. 


\section{Yinternational Research Journal}

p-ISSN 2202-2821 e-ISSN 1839-6518 (Australian ISSN Agency)

Compared to Sri Aurobindo and Kailasam, other major playwrights like Harindranath Chattopadhyaya and Bharati Sarabhai are less influenced by Elizabethan drama. Chattopadhyaya presents the lives of the Indian saints in an almost traditional manner. Though he does not directly follow the models and techniques of our classical as well as folkstage, the shadow of the Sutradhara in the form of a Preface, as in Jayadeva, can be noticed easily. Asif Currimbhoy also let his one act plays to be influenced by western models. But, most of his plays may fail on the stage on account of his excessive dependence on cinematographic techniques and other stage gimmicks. Thus it is clear from the survey that the playwrights have, by and large, ignored our ancient dramatic tradition, though here and there a few experiments in this regard can be noticed. This is perhaps an important reason why Indian drama in English has remained mostly derivative and imitative.

Modern Indian English Drama has the immense scope for traditional techniques. It has the courage to give new dimensions to traditional theatrical perceptions. It not only uses old conventions but gives them new meanings also. So it is never a blind imitation of classical drama but evolves its new theory and takes drama to the common man. Modern Indian English Drama is not the offspring of any specific tradition rather it has laid the foundation of a distinctive tradition in the field of drama by exploring new vistas through reinvestigation into history, legend, myth, folklore and contemporary socio-political issues. A whole new theatrical perception is evolved by the modern Indian English Playwrights like Girish Karnad, Vijay Tendulkay, Habib Tanvir and Badal Sircar.

Girish Karnad was well aware of the challenges which Indian playwrights had to face after independence. They "had to face a situation in which tensions implicit until then had come out in the open and demanded to be resolved without apologia or self justification: tensions between the cultural past of the country and its colonial past, between the attractions of western modes of thought and our own tradition, And finally between the various visions of the future that opened up once the common cause of political freedom was achieved." (Dodiya 21). So in such a scenario Drama was to fulfill great expectations and dedicate itself entirely to the noble cause of building a new nation. Modern Indian Dramatists, definitely, have taken the cause in their hands. Girish Karnad's genius lies in the fact that he draws a parallel between antiquity and contemporariness. His plays like Yayati, Tughlaq, Hayavadana, Nagamandal, Tale Danda and Fire and the Rain are based on History, Myths and legends. He explored new vistas to further Indian English Drama. In Sanskrit plays there have been the uses of Nandi, Bhagavat,
Vol. 06 No. 012016 82800601201602

masks, puppets and the like. Girish Karnad "went back to myths and legends and made them a vehicle of a new vision."( Dodiya 44) Through Karnad Modern Indian English Drama gets new ways to address social and individual issues. He finds the Sanskrit plays worthier to be staged than the plays of Tagore and Aurbindo.

While Karnad uses historical and mythical set-up, Badal Sircar, the great Bangali playwright uses contemporary scenario to throw light on the social problems of modern man. 'Utter meaninglessness on human existence' is the chief theme of his plays. He wants to go from village to village and involve the people. His great contribution lies in his Third Theatre. It is also called Street Theatre. It has brought revolutionary change in the concept of Dramatic performances. Through this theatre, Sircar addresses not only socio-political but ecological issues also. This theatre is the result of growing unemployment among educated youth. It is very cheap and mobile medium that would, besides many more, serve the purpose of forming a society based on equality. Nivedita Tandon says, "Various issues of social and ecological concerns are voiced through this medium of theatre. They seek to enlighten the masses on a plethora of social an, political, religious, economic, communalism, caste, disparities, terrorism, nuclear disastes, corruption, and AIDS awareness find a place in the repertory of street plays." (104)

Iconic Marathi dramatist, Vijay Tendulkar kicks-off a virtual revolution in Indian theatre both in terms of content and style. $\mathrm{He}$ is a subtle observer of Indian social reality. $\mathrm{He}$ is a humanist, an innovative playwright who continuously experimented with form and structures. He is known for his insightful "objectification" in the development of multilayered characters whose existential angst was held up against the social traumas of the society. Tendulkar's plays have dealt with themes that unravel the exploitation of power and latent violence in human relationships. Leading the Vanguard of the avant-garde Marathi Theatre, Vijay Tendulkar symbolizes the new awareness and attempts of Indian dramatists of the century to depict the agonies, suffocations and cries of man. In all his plays, he works upon the theme of isolation of the individual and his confrontation with the hostile surroundings. Habib Tanvir's genius lies in his deployment of folk elements like Karnad. He touched new horizons with his Chhattisgarhi folk troupe. He founded 'New Theatre' in Bhopal in 1959. Nach, chorus that provides commentary with song, is his novel contribution to Drama. Besides, he experimented with 'Pandavani' a folk musical form. Not only this, the contribution of many more like Mahesh Dattani, Indira Parthasarathy, Mahasweta Devi and Padamanabhan also 
cannot be ignored whenever Modern Indian English Drama is talked about. So Modern Indian English Dramatists dare to defy the professional stage established by the previous playwrights. They have the genius and the power to transform any situation into an aesthetic experience. They really deserve hats-off salute and a standing ovation for exploring new vistas and confirming the novel identity of drama among storytelling and poetry.

\section{References}

[1]. Iyengar, K R Srinivasa. Indian Writing in English. Sterling Publication Private Limited, New Delhi:2006.Print.

[2]. Karnad, Girish. Three Plays. Oxford University Press, New Delhi, 2009. Print.

[3]. "Introduction to Three Plays: Naga-Mandala, Hayavadana, Tughlaq.”ed. J.Dodiya, Prestige Books, New Delhi:2009. Print.

[4]. Naik, M.K, and Mokashi-Punekar, S., eds. Perspectives on Indian Drama in English . O.U.P., Madras: 1977. Print.

[5]. Shukla, Supriya. "Indian-English Drama: An Introduction."Perspectives and Challenges in

[6]. Indian-English Drama. Ed. Neeru Tendon, Atlantic Publishers, New Delhi: 2006. Print.

[7]. Tandon Nivedita. "Street Theatre In India: Badal Sircar's Countribution in the Form of Third Theatre"Perspectives and Challenges in IndianEnglish Drama. ed. Neeru Tandon, Atlantic Publishers, New Delhi: 2006. Print. 